\title{
Sistem Kendali Penyiram Tanaman Menggunakan Propeller Berbasis Internet Of Things
}

\author{
Ratnawati ${ }^{1}$, Silma $^{2}$ \\ Sistem Informasi, STMIK AKBA ${ }^{1}$,Teknik Informatika ${ }^{2}$, STMIK AKBA

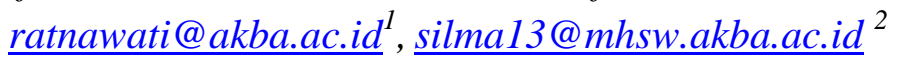

\begin{abstract}
ABSTRAK
Penyiraman tanaman yang masih manual menjadikan tanaman tidak terawat dengan baik karena waktu aktifitas yang padat, atau jenis tanaman yang dimiliki memiliki perhatian khusus baik secara tempat yang harus sejuk dan kebutuhan air yang harus tetap terpenuhi.Jika penyiraman tanaman ini bisa dilakukan secara otomatis oleh bantuan alat maka akan sangat bermanfaat dan lebih mempermudah dalam proses perawatan tanaman. Penelitian ini bertujuan untuk merancang sebuah alat penyiram tanaman otomatis dengan menggunakan propellerdan sensor moinsture sebagai alat untuk mendeteksi kadar kelembaban tanah. Data diperoleh melalui (1) Penelitian Lapangan (2) Penelitian Pustaka (3) Wawancara. Hasil penelitian ini menunjukkan bahwa prototype penyiram tanaman menggunakan propeller berbasis internet of things dapat mempermudah dan menghemat waktu.
\end{abstract}

\section{Kata Kunci :Propeller, Internet Of Things, Sensor Monisture}

\section{Pendahuluan}

Tanaman merupakan makhluk hidup penting yang tak bisa terpisahkan dengan kehidupan manusia.Air merupakan salah satu bagian terpenting untuk pertumbuhan tanaman.Tanpa perawatan intensif tanaman bisa saja mati.Maka dari itu butuh perhatian khusus untuk mengoptimalkan pertumbuhannya.Tanaman yang sehat harus diikuti dengan kondisi tanah yang baik.Kondisi tersebut adalah nilai kelembapan tanah yang ideal dan seimbang. Terlalu basah atau kering akan kurang baik bagi keberlangsungan hidup tanaman tersebut.

Happy Nugrahaning Widhi (2014), dalam penelitiannya "Sistem Penyiraman Tanaman Anggrek Menggunakan Sensor Kelembaban dengan Program Borland Delphi 7 Berbasis Modul Arduino Uno
R3" menyimpulkan mikrokontroler arduino menerima inputan data dari sesor kelembaban kemudian mengolahnya dan memberikan outputan printah melalui relay.

Penelitian ini membuat sebuah alat penyiram tanaman secara otomatis dalam penelitian yang berjudul "Sistem Kendali Penyiram Tanaman Menggunakan Propeller Berbasis Internet Of Things". Alat yang digunakan untuk mengolah data inputan dari sensor pada penyiram tanaman berbasis Internet Of Things ini adalah wemos D1.

Alat ini disertai dengan wifi sehingga kita bisa menghubungkan alat dengan aplikasi pada smartphone. Dengan adanya aplikasi ini maka kadar kelembaban tanah yang tampil pada layar $L C D$ akan dikirim ke aplikasi pada smartphone. Aplikasi 
yang digunakan adalah Blynk.Manfaat yang didapatkan dari penelitian ini adalah menghasilkan prototype berupa penyiram tanaman secara otomatis dengan mendeteksi kadar kelembapan tanah

\section{Tujuan Penelitian}

Tujuan dari penelitian ini adalah merancang dan mengimplementasikan alat penyiram tanaman menggunakan propeller berbasis internet of things.

\section{Metodologi Penelitian}

Tahapan dalam penelitian dapat dilihat pada gambar 1:

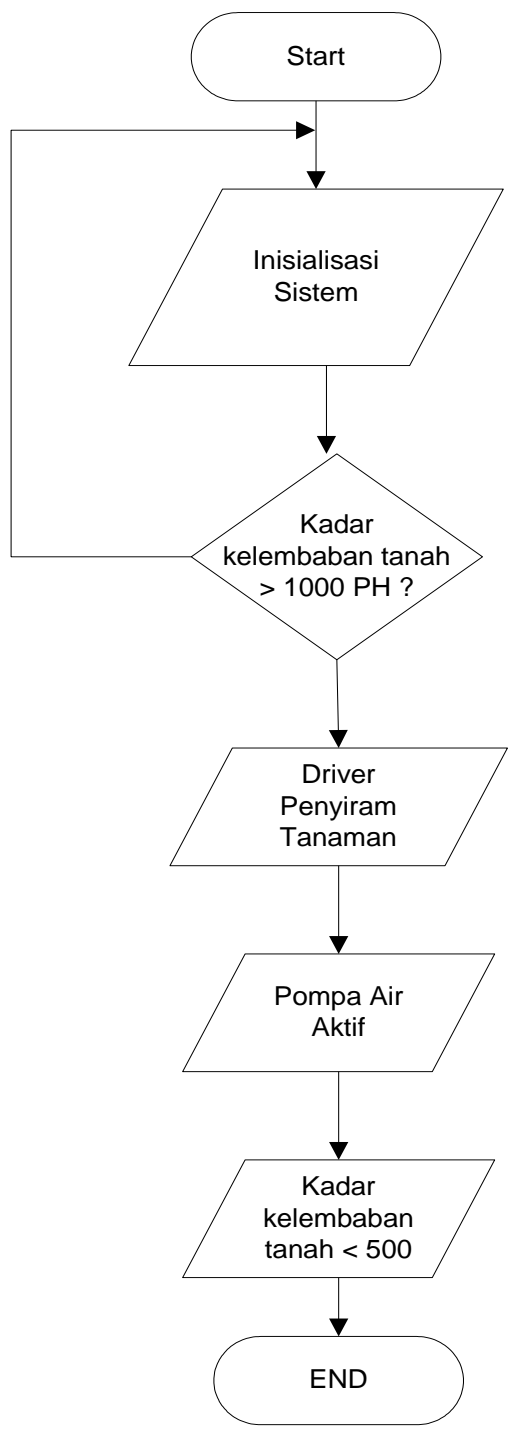

Gambar 1. Prosedur Penelitian

\section{Kajian Pustaka}

\section{a. Mikrokontroler}

Mikrokontroler adalah Control Processing Unit (CPU) yang disertai dengan memori dan sarana inputoutput yan dibuat dalam bentuk chip. Salah satu mikrokontroler yang banyak digunakan saat ini adalah AVR. Mikrokontroler AVR merupakan pengontrol utama standar industry dan riset saat ini. Hal ini dikarenakan berbagai kelebihan yang dimilik, disbanding microprocessor yang lebih murah, dukungan software serta dokumentasi yang memadai dan memerlukan komponen pendukung yang sangat sedikit. Dalam hal ini, mikrokontroler yang digunakan adalah mikrikontroler AVR ATmega328P (Arduino Uno).

1). Karakteristik Mikrokontroler Karakteristik mikrokontroler mempunyai beberapa komponenkomponen yaitu:

a). CPU (Central Procesing Unit)

b). RAM (Read Only Memory)

c). I/O (Input/Output)

Ketiga komponen tersebut secara bersama-sama membentuk sistem komputer dasar. Beberapa mikrokontrol memiliki tambahan komponen lain, misalnya ADC (Analog Digital Converter), Timer/Counter, dan lain-lain.

2). Klasifikasi Mikrokontroler Mikrokontroler memiliki beberapa klasifikasi yaitu sebagai berikut:

a). ROM (Flash Memory) dengan kapasitas 1024 byte $(1 \mathrm{~KB})$

b). RAM berkapasitas 68 byte

c). EEPROM (memori data) berkapasitas 64 byte

d). Total 13 jalur I/O (Port B 8 bit) 
e). Timer/Counter 8 bit dengan prescaler

f). Fasilitas pemrograman di dalam sistem $(\mathrm{ICSP}=$ In Circuit Serial Programing)

\section{b. Arduino}

Arduino merupakan rangkaian elektronik yang bersifat open source, serta memiliki perangkat keras dan lunak yang mudah untuk digunakan. Arduino memiliki kelebihan tersendiri dibanding board mikrokontroler yang lain selain bersifat open source, arduino juga mempunyai bahasa pemrogramanya sendiri yang berupa bahasa C. Arduino dapat mengenali lingkungan sekitarnya melalui berbagai jenis sensor dan dapat mengendalikan lampu, motor, dan berbagai jenis aktuator lainnya. Arduino mempunyai banyak jenis, di antaranya Arduino Uno, Arduino Mega 2560, Arduino Fio, danlainnya.

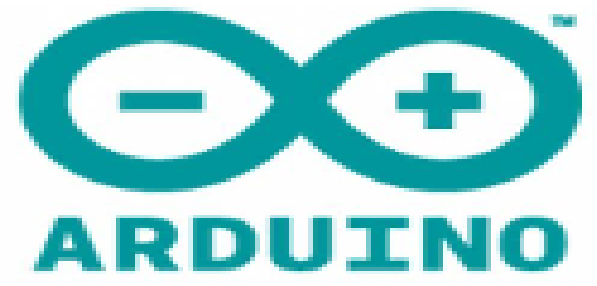

Gambar 2. Logo Arduino

\section{c. Internet Of Things}

Istilah Internet of Things adalah sebuah konsep dimana suatu objek yang memiliki kemampuan untuk mentransfer data melalui jaringan tanpa memerlukan interaksi manusia ke manusia atau manusia ke komputer. Internet of thingspertama kali dimunculkan oleh Kevin Ashton pada tahun 1999 di salah satu presentasinya, cofounder and executive director of the Auto-ID Center di MIT. Pada dasarnya,
Internet of things mengacu pada benda yang dapat diidentifikasikan secara unik sebagai representasi virtual dalam struktur berbasis Internet.

Internet of Things memiliki potensi untuk mengubah dunia seperti yang pernah dilakukan oleh Internet, bahkan mungkin lebih baik. Penelitian pada Internet of Things masih dalam tahap perkembangan. Oleh karena itu, tidak ada definisi standar dari Internet of Things.Terdapat juga berbagai definisi yang dirumuskan oleh peneliti yang berbeda serta tercantum dalam survei. Di dalam membangun Internet Of Things para engineer harus memperhatikan ketiga aspek yaitu : Ukuran, ruang, dan waktu.Dalam melakukan pengembangan Internet of Things faktor Waktu yang biasanya menjadi kendala.

Fungsi utama dari Internet of Things adalah sebagai sarana yang memudahkan untuk pengawasan dan pengendalian barang fisik maka konsep Internet Of Things ini sangat memungkinkan untuk digunakan hampir pada seluruh kegiatan seharihari, mulai dari penggunaan perorangan, perkantoran, rumah sakit, pariwisat, industri, transportasi, konserverasi hewan, pertanian dan peternakan, sampai ke pemerintahan. Internet of Things juga sangat berguna dalam otomatisasi seluruh perangkat yang terhubung ke internet dimana konfigurasi otomatisasi tersebut dapat di sesuaikan dengan mudah tanpa harus datang ke lokasi perangkat tersebut. Baik untuk alasan keamanan untuk wilayah yang tidak mungkin dimasuki manusia, maupun untuk alasan jangkauan terhadap 
perangkat yang akan di kendalikan tersebut.

\section{Metodo Penelitian}

Metode yang dipergunakan dalam penelitian ini adalah metode eksperimental, yaitu perancangan dan pembuatan sistem

\section{Analisis Kebutuhan Sistem}

Pada tahap ini menjelaskan apa saja yang dibutuhkan pada sa at perancangan. Adapun kebutuhan yang akan digunakan adalah:

\section{a. Kebutuhan perangkat keras}

Adapun perangkat keras yang digunakan dalam pembuatan perangkat ini adalah:
1) Laptop acer
2) Smartphone
3) Wemos D1
4) Sensor kelembaban tanah
5) $L C D$
6) Relay

b. Kebutuhan perangkat lunak

Selain perangkat keras, dibutuhkan juga perangkat lunak dalam pembuatan, perangkat lunak minimum yang dibutuhkan adalah sebagai berikut:
1) Arduino IDE
2) Windows 10

\section{Kebutuhan Alat dan Bahan}

Alat penelitian yang diperlukan pada penelitian ini berupa :

1) Borlistrik

2) Solder listrik

3) Pemotongan pcb portal

4) Multi meter

bahan penelitian yang akan digunakan adalah :

1). Pompa

2). Papan PCB
3). Timah

4). Kabel Pelangi

5). Broadbeard

\section{Analisis Kebutuhan Sistem}

Pembuatan blok diagram ini bertujuan sebagai acuan pembuatan perangkat keras. Pada perancangan ini penulis merancang sistem dalam blok-blok sebagai gambaran untuk memudahkan penulis dalam merangkai sebuah rangkaian terpadu. Blok diagram dapat dilihat pada gambar 3.

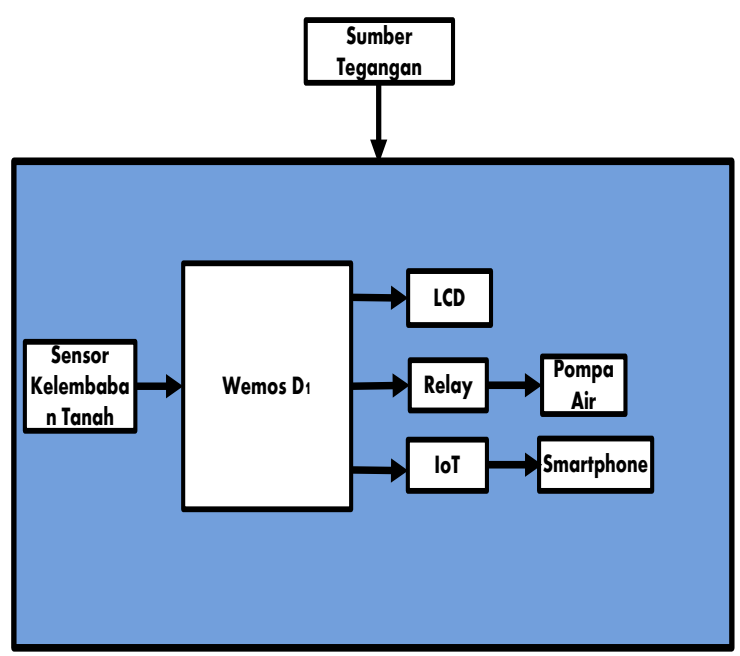

Gambar 3. Blok Diagram Sistem

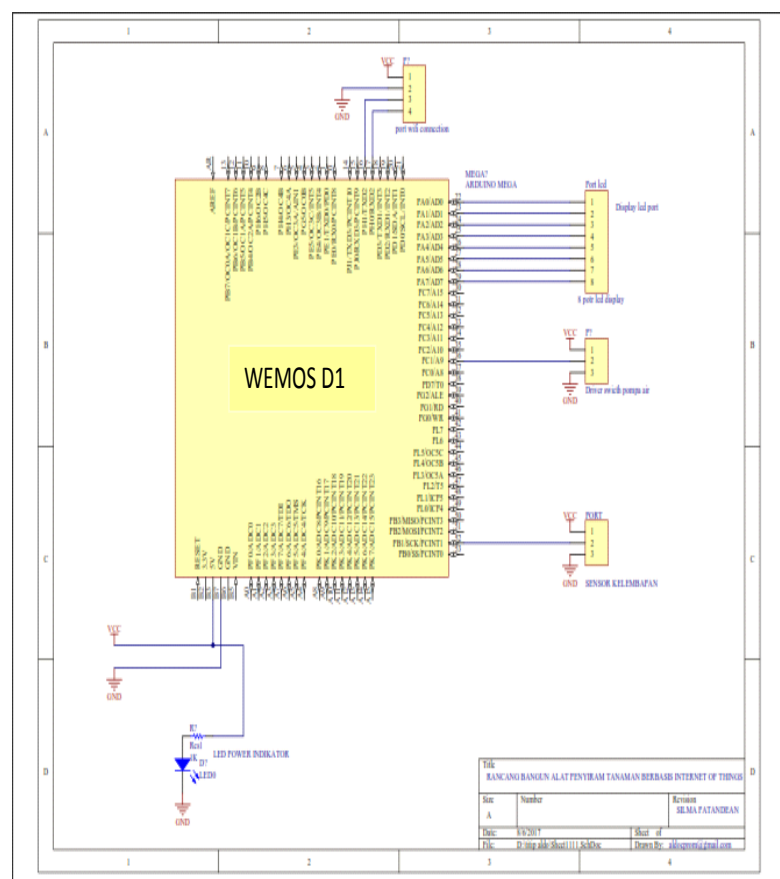

Gambar 4. Rangkaian Skematik 


\section{Hasil Perancangan}

Berdasarkan hasil perancangan alat penyiram tanaman otomatis berbasis Internet Of Things maka alat ini dirancang telah selesai yaitu alat penyiram tanaman menggunakan sensor kelembaban dan sensor cahaya untuk mendeteksi kadar kelembaban tanah. Apabila kadar kelembaban diaatas atau sama dengan 1000 nilai kelembaban tanah maka pompa akan menyiram secara otomatis dan akan berhenti apabila kadar kelembaban tanah dibawah atau sama dengan 500 nilai kelembaban tanah.

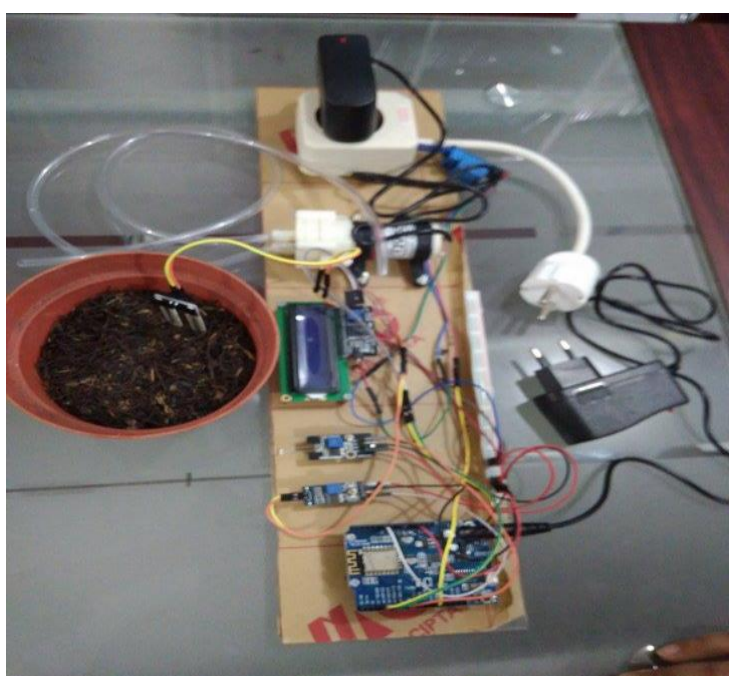

Gambar 5. Hasil Perancangan Alat

\section{a. Spesifikasi Alat}

Adapun spesifikasih alat yang di buat adalah sebagai berikut :

1). Didesain untuk menyiram secara otomatis

2). Menggunakan sensor kelembaban dan sensor cahaya

3). Menggunakan wemos D1

4). Menggunakan pompa air

5). Tegangan sumber yang digunakan 12 Volt yang menyuplai rangkaian secara keseluruhan

6). Menggunakan LCD

7). Menggunakan relay 5 Volt

\section{b. Pemrograman Arduino}

Perancangan perangakat lunak untuk pembuatan kode program menggunakan software arduino IDE. Berikut adalah cara membuat project baru pada arduino IDE.

Langkah-langkah untuk memprogram Wemos dengan Arduino IDE :

1). Tampilan awal Arduino
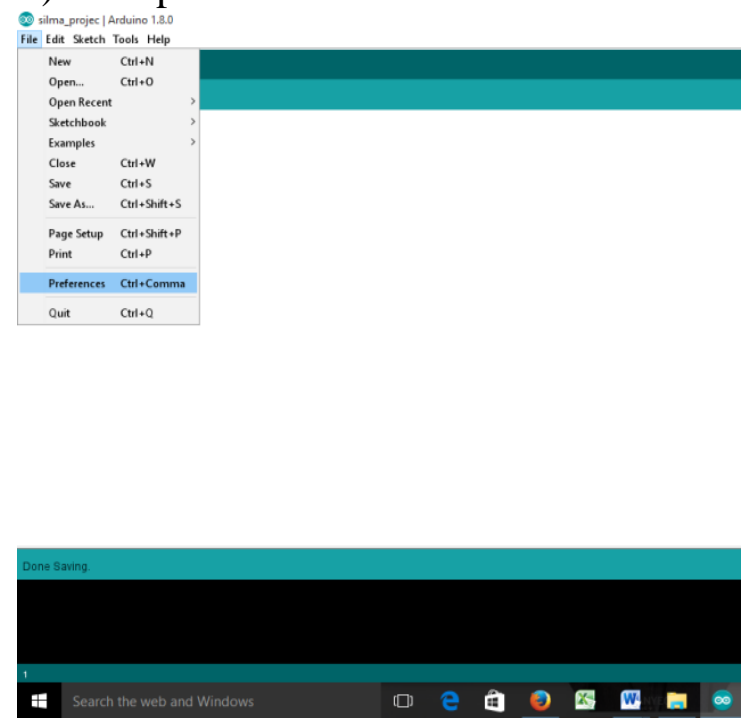

Gambar 6. Tampilan awal Arduino

2). Additional Board Manager URL

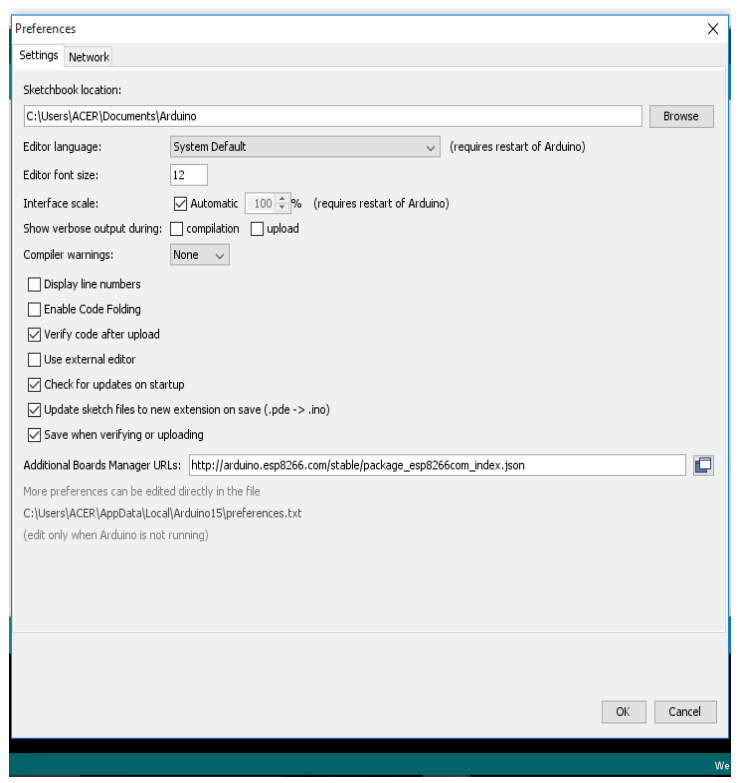

Gambar 7. Additional Board Manager $U R L$ 
3). Mengatur jenis port

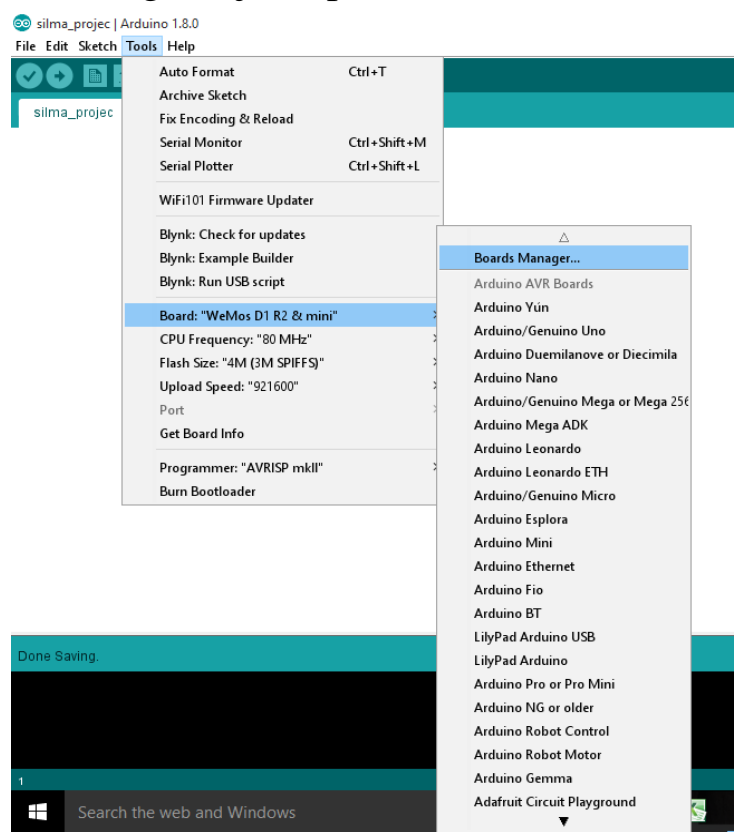

Gambar 8. cara mengatur jenis board

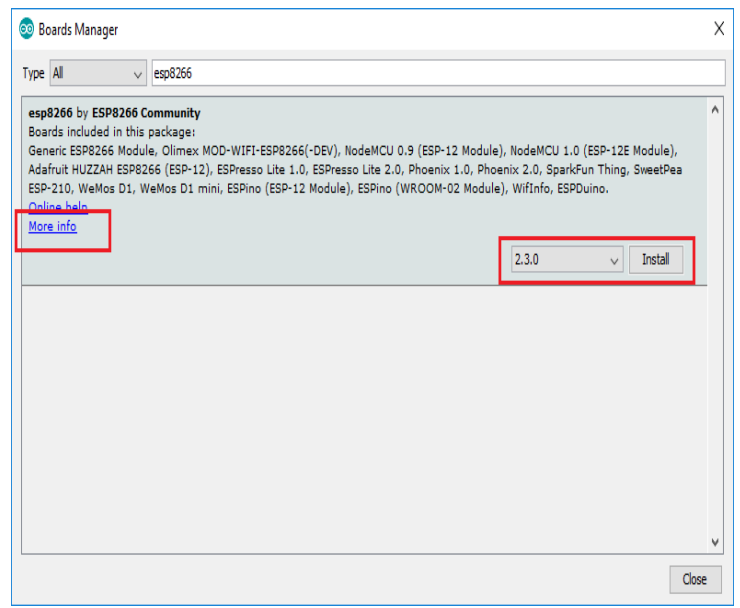

Gambar 9.Tampilan Board Manager

4). Cara mengatur Port

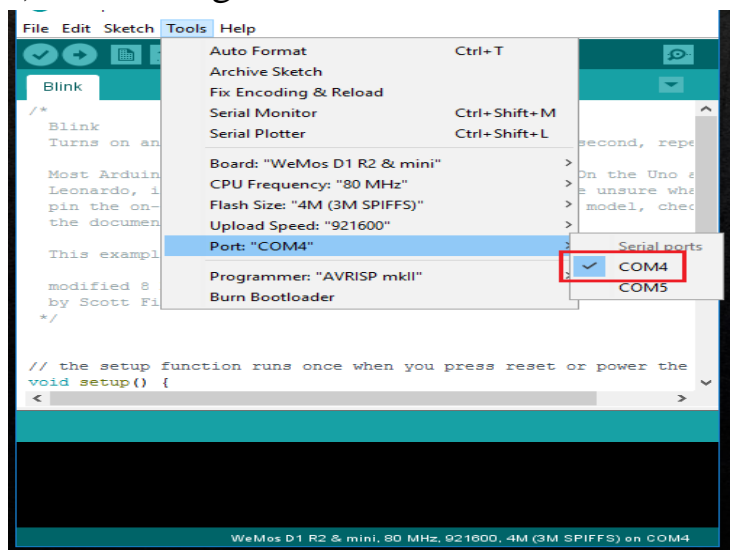

Gambar 10.Cara Mengatur Jenis Port
5). Tampilan aplikasi Blynk

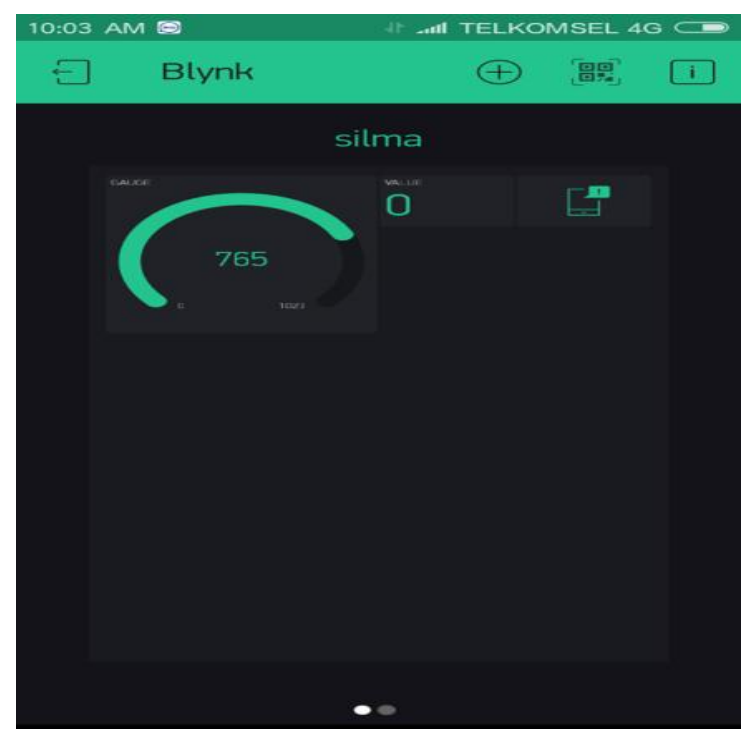

Gambar 11. Tampilan Aplikasi Blynk

\section{Pengujian Alat}

Proses pengujian alat penyiram tanaman menggunakan propeller berbasis Internet of Things dilakukan secara bertahap. Dengan menguji kinerja dari setiap komponen. Adapun pengujiannya sebagai berikut :

\section{a. Pengujian relay}

Pengujian ini dilakukan dengan cara menghubungkan pin driver relay ke modul wemos DI dan memprogram untuk mengetahui apakah relay dapat bekerja atau tidak serta memberikan nilai High dan Low pada keluar menuju relay. Pada saat sensor tanah mendeteksi kadar kelembaban tanah maka sensor mengirim data ke wemos $D 1$ dan mengaktifkan relay yang terhubung ke pompa air. Hasil pengujian relay dapat dilihat pada table 1.

Tabel 1. Pengujian Relay

\begin{tabular}{|c|l|l|l|}
\hline $\begin{array}{c}\text { Tegangan } \\
\text { Input }\end{array}$ & $\begin{array}{c}\text { Output } \\
\text { Tegangan }\end{array}$ & Logika & \multicolumn{1}{|c|}{ Ket } \\
\hline \multirow{2}{*}{$5 \mathrm{~V}$} & $0.9 \mathrm{~V}$ & Low & $\begin{array}{l}\text { Pompa } \\
\text { tidak aktif }\end{array}$ \\
\cline { 2 - 4 } & $4.95 . \mathrm{V}$ & High & $\begin{array}{l}\text { Pompa } \\
\text { aktif }\end{array}$ \\
\hline \multicolumn{2}{|c|}{ Dari pengujian tersebut diketahui } \\
\hline
\end{tabular}
output relay akan bernilai $L O W$ jika output 
tegangan bernilai $0.9 \mathrm{~V}$, sedangkan output relay bernilai $H I G H$ jika output tegangan bernilai $4.95 \mathrm{~V}$

\section{b. Pengujian Internat of Things}

Implementasi penyiram tanaman ini bekerja apabila hostpot pada smartphone aktif. Dan kadar kelembaban tanah yang tampil pada layar $L C D$ akan tampil secara otomatis pada aplikasi Blynk yang ada dalam smartphone.

\section{c. Pengujian Sensor kelembaban dan Sensor Cahaya}

Tabel 2. Hasil pengujian sensor

\begin{tabular}{|c|c|c|c|}
\hline No & Kelembaban & Cahaya & $\begin{array}{c}\text { Kondisi } \\
\text { Pompa }\end{array}$ \\
\hline 1 & $>=1000$ & 0 (Terang) & Menyiram \\
\hline 2 & $<=500$ & 0 (Terang) & $\begin{array}{c}\text { Tidak } \\
\text { Menyiram }\end{array}$ \\
\hline 3 & $>=1000$ & 1 (Gelap) & $\begin{array}{c}\text { Tidak } \\
\text { Menyiram }\end{array}$ \\
\hline
\end{tabular}

Dari table 2 terlihat bahwa kelembaban diatas 1000 dan sensor cahaya bernilai 0 keadaan pompa akan menyiram, kelembaban dibawah 500 dan sensor cahaya bernilai 0 pompa tidak menyiram serta saat kelembaban diatas 1000 dan nilai sensor cahaya bernilai 1 pompa tidak menyiram. Pengujian dilakukan dengan cara membenamkan probe sensor kedalam tanah dan sensor akan membaca kelembaban tanah secara langsung.

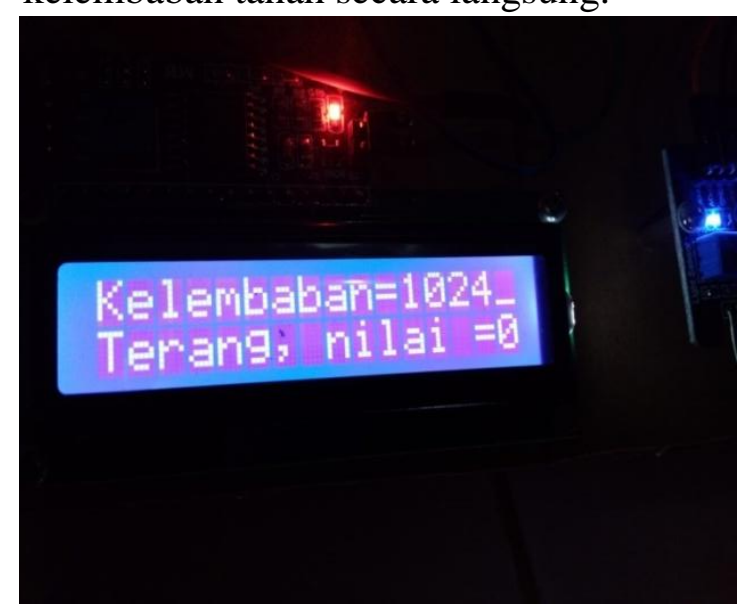

Gambar 12.Tampilan LCD saat Kadar Tanah kering
Gambar 12 menunjukkan bahwa pada saat kadar air 1024 dan sensor cahaya bernilai 0 (terang), relay dan pompa akan aktif (menyiram).

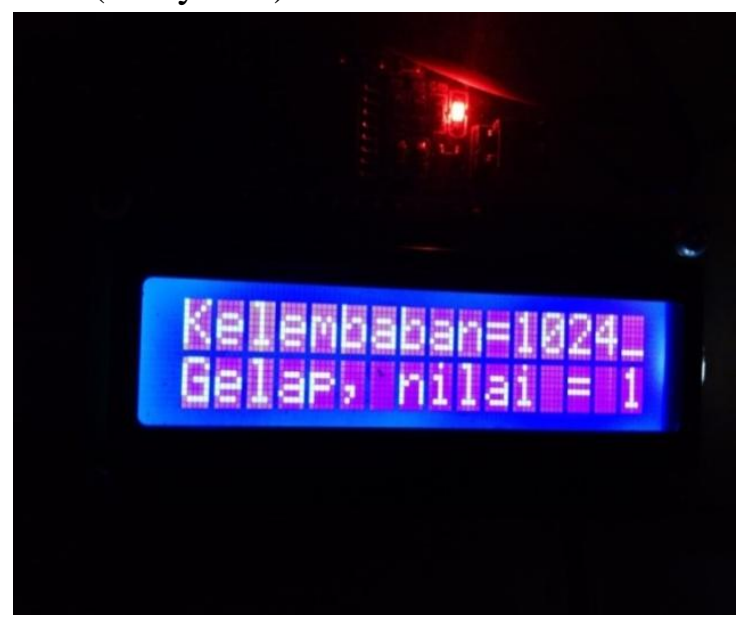

Gambar 13.Tampilan LCD saat Kadar Tanah kering

Gambar 13. menunjukkan bahwa pada saat kadar air 1024 dan nilai sensor cahaya bernilai 1 (gelap) relay dan pompa tidak aktif (tidak menyiram).

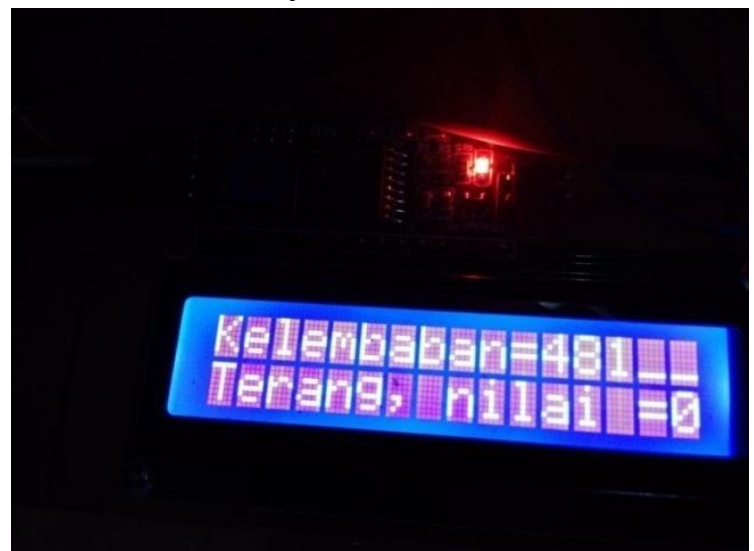

Gambar 14.Tampilan LCD saat Kadar Tanah lembab

Gambar 14. menunjukkan bahwa pada saat kadar kelembaban tanah 481 dan sensor cahaya bernilai 0 (terang) relay dan pompa air tidak aktif (tidak menyiram).

\section{Kesimpulan}

1). Sistem penyiram tanaman berbasis Internet Of Things menggunakan soil moinsture sensor dan sensor cahaya telah berhasil di buat dan di uji coba 
menggunakan Wemos D1, LCD, Relay, dan pompa air.

2). Alat ini dapat di implementasikan dan siap untuk digunakan. Sistem ini bekerja dengan baik berdasarkan nilai kelembaban tanah yang dideteksi oleh sensor kelembaban. Dari beberapa pengujian yang telah dilakukan diperoleh kadar tanah yang paling baik dengan nilai 600 $\mathrm{PH}$.

\section{Daftar Pustaka}

[1].Hanan Wisnu Wijaya., B. S. (2017). PERANCANGAN ALAT PENYIRAM TANAMAN OTOMATIS DENGAN YL69 BERBASIS ARDUINO UNO R3.

[2].Happy Nugrahaning Widhi., H. W. (2014). Sistem Penyiraman Tanaman Anggrek Menggunakan Sensor Kelembaban dengan Program Delphi 7 Berbasis Modul Arduino Uno R3, 4145 .

[3].Hartono, M. (2016). Pot Tanaman Pintar Berbasis Internet Of Things Pada RSUD Kota Tangerang.

[4].Muhammad Izzuddin Al-Muqorrobin., A. N. (2015). Penyiraman Otomatis Pada Tanaman Atap Rumput Gajah, 83-93.

[5]. Saputra, R. S. (2015). Prototipe Sistem Informasi Cuti Karyawan Berbasis Web Pada PT.Surya Toto Indonesia.

[6].Syahputra, H. A. (2017). Mesin Penjualan Alat Tulis Otomatis pada SMK Mandiri 2 Balaraja.

[7].Widhi, H. N. (2014). Sistem Penyiram Tanaman Anggrek Menggunakan Sensor Kelembaban Dengan Program Borland Delphi 7 Berbasis Modul Arduino Uno R3.
[8]. Yahwe, C. P. (2016). Rancang Bangun Prototype system Monitoring Kelembaban Tanah Melalui SMS Berdasarkan Hasil Penyiram Tanaman "Studi Kasus Tanaman Cabai Dan Tomat". 